\title{
Effects on ventricular arrhythmias of oral captopril and of oral mononitrate started early in acute myocardial infarction: results of a randomised placebo controlled trial
}

Athanase Pipilis, Marcus Flather, Rory Collins, Allister Hargreaves, Theophilos Kolettis, Nicholas Boon, Clare Foster, Paul Appleby, Peter Sleight

\begin{abstract}
Objective-To assess the effects of oral vasodilator treatment on ventricular arrhythmias in acute myocardial infarction.
\end{abstract}

Setting-Coronary care units at the John Radcliffe Hospital, Oxford, and the Royal Infirmary, Edinburgh.

Patients-100 patients with suspected acute myocardial infarction entered the study at a mean of 13 hours from symptom onset.

Design of Intervention-Double blind randomisation to 4 weeks' treatment with captopril (12.5 $\mathrm{mg}$ three times a day after a $6.25 \mathrm{mg}$ test dose $(\mathrm{n}=32)$ ) or isosorbide mononitrate $(20 \mathrm{mg}$ three times a day $(\mathrm{n}=$ $31)$ ) or placebo control $(n=37)$.

Outcome measures-Ventricular arrhythmic events assessed by 48 hours of Holter monitoring starting at the time of randomisation.

Results-The number of ventricular extrasystoles/hour for captopril, mononitrate, and placebo was respectively (median and range) $6(0-162), 4(0-38)$, and $10(0-932)(2 \mathrm{p}<0.02$ mononitrate $v$ placebo). The number of episodes of multiple extrasystoles/hour was $0.2(0-22), 0 \cdot 3$ $(0-4)$, and $0.5(0-19)$; $(2 p<0.02$ mononitrate $v$ placebo). Episodes of ventricular tachycardia showed a non-significant decrease in the captopril and mononitrate groups (mean (SEM) 3.2 (0.8), $2.4(0.7)$, and $4 \cdot 7(1 \cdot 3)$ for the 48 hour period). The incidence of idioventricular rhythm was also reduced in both active treatment groups $(28 \%, 19 \%$, and $46 \%(2 \mathrm{p}<0.05$ mononitrate $v$ placebo)).

Conclusions-Oral mononitrate (and perhaps also captopril) seems to reduce the incidence of ventricular arrhythmias in the early phase of acute myocardial infarction. The effects on life-threatening arrhythmias, such as ventricular fibrillation, and on death can only be assessed in a much larger trial.

\section{(Br Heart f 1993;69:161-165)}

The renin-angiotensin system is activated during the first few days after acute myocardial infarction, ${ }^{12}$ leading to stimulation of the heart and to increased systemic and coronary vascular resistance. ${ }^{3}$ Increases in systemic vas- cular resistance may increase myocardial wall stress, predisposing to infarct expansion, aneurysm, or progressive ventricular dilatation during the recovery phase after infarction. ${ }^{4-5}$ Moreover, both in experimental models and in clinical studies, increases in wall stress have been shown to increase the frequency of ventricular arrhythmias, whereas a reduction in wall stress has the opposite effect. ${ }^{67}$ Studies of patients in whom treatment with angiotensin converting enzyme inhibitors ${ }^{8-10}$ and nitrates ${ }^{11}$ was started after acute myocardial infarction indicate that these agents can reduce systemic vascular resistance in acute myocardial infarction with favourable effects on the remodelling process. Intravenous glyceryl trinitrate can also reduce ventricular arrhythmias after acute myocardial infarction, ${ }^{12}{ }^{13}$ and similar observations have been made with angiotensin converting enzyme inhibitors among patients with congestive heart failure. ${ }^{1415}$ There have, however, been no controlled studies of the effects of oral nitrates or of angiotensin converting enzyme inhibitors on arrhythmias in acute myocardial infarction. In the present study, therefore, 48 hour Holter monitoring was carried out as part of a randomised placebo controlled trial of oral captopril versus oral isosorbide mononitrate versus placebo control in patients with suspected myocardial infarction (ISIS-4 Pilot Study).

\section{Patients and methods}

PATIENTS

Between September 1988 and July 1990, 273 patients with suspected acute myocardial infarction admitted to the coronary care units of the John Radcliffe Hospital and the Edinburgh Royal Infirmary were randomised in a placebo controlled study of oral captopril (an initial dose of $6.25 \mathrm{mg}$ followed two hours later by $12.5 \mathrm{mg}$ and then by $12.5 \mathrm{mg}$ three times a day) versus isosorbide mononitrate (an initial dose of $20 \mathrm{mg}$ followed by $20 \mathrm{mg}$ three times a day) versus matching placebo, with trial treatment continued for four weeks. Patients were eligible if symptoms of suspected acute myocardial infarction had started less than 36 hours before and there were no clear indications for, or contraindications to, oral converting enzyme inhibitors or oral nitrates (for example, cardiogenic shock, persistent severe hypotension, or severe fluid depletion) and no major life-threatening condition other than 
myocardial infarction. Eligible patients were randomised by a central 24-hour telephone randomisation service which allocated a specific trial pack, containing calendar-packed trial treatment, after all baseline data for the patient had been recorded. Apart from complying with trial treatment and avoiding nontrial converting enzyme inhibitors and nitrates unless considered clearly indicated, physicians managed patients entirely at their own discretion.

RECORDING AND ANALYSIS OF ARRHYTHMIAS

Holter tape recorders were available to start 48 hour electrocardiographic recording at the time of randomisation in 110 patients. After the usual skin preparation, CM5 and modified II leads were recorded by Oxford Medilog MR 35FM two-channel recorders (John Radcliffe Hospital) or the CM5 lead alone was recorded by Oxford Medilog MR 14A single-channel recorders (Edinburgh Royal Infirmary). The electrocardiographic analysis was performed by an Oxford Medilog 3000FM analyser for the two-channel tapes and an Oxford Medilog Excell analyser for the single-channel tapes. All analysis was done by the same operator (AP), without any knowledge of the patient's treatment regimen. A hundred tapes were of adequate quality for reliable analysis. Arrhythmic events were recorded for each hour, with QRS triggering and detection of extrasystoles checked visually, and the following definitions were used:

Ventricular extrasystoles-Abnormal QRS shaped beats without a preceding $P$ wave.

Multiple extrasystoles-Two or three consecutive ventricular extrasystolic beats with a rate $<110 / \mathrm{min}$.

Idioventricular rhythm-Four or more consecutive ventricular extrasystoles of the same configuration with a rate $<110 / \mathrm{min}$.

Ventricular tachycardia-Three or more consecutive ventricular extrasystoles with a rate $\geqslant 110 / \mathrm{min}$.

Arrhythmia frequency is much higher during the first few hours after the onset of infarction. For each patient, therefore, the numbers of ventricular extrasystoles/hour, of multiple extrasystole episodes/hour, and of ventricular tachycardia episodes, and the incidence (\% of patients) of arrhythmias were calculated not just for the whole 48 hour period but also for the first six hours.

STATISTICAL ANALYSIS

Values are presented as means (SEM), median (and range), or percentages as appropriate. Because the number of ventricular extrasystoles is not normally distributed in patients with acute myocardial infarction (with individual values for a 24 hour period ranging from just a few to some tens of thousands that is, distribution skewed to the right) these values were logarithmically transformed for statistical comparisons. Analysis of variance was used to compare the frequency of arrhythmic events in the three treatment groups and only if the $p$ value was less than 0.05 were two-way comparisons carried out by Student's unpaired $t$ test.
The incidence of ventricular arrhythmias was compared by the $\chi^{2}$ test.

\section{Results}

\section{PATIENT CHARACTERISTICS}

Baseline pre-randomisation characteristics were similar in all three groups (table 1): $84 \%$ of patients were male, the mean (SEM) age was 61 (2) years, the mean systolic blood pressure was 127 (2) $\mathrm{mm} \mathrm{Hg}$ (with no patients with entry systolic pressure persistently below $100 \mathrm{~mm} \mathrm{Hg}$ ), and the mean heart rate was 75 (2) beats per minute (with only five patients with an entry heart rate above 100 beats per minute). Patients were randomised at a mean of 13 (1) hours from the onset of symptoms of suspected acute myocardial infarction and $85 \%$ had ST segment elevation on the initial electrocardiogram (36\% in anterior leads, $47 \%$ in inferior leads alone, and $2 \%$ in both or other leads). There were slightly more patients with anterior wall infarcts in the captopril group, though this excess was not statistically significant. After randomisation, infarction was confirmed by diagnostic electrocardiographic or enzyme criteria in $98 \%$ of patients. Compliance with trial treatment during the 48 hour period of Holter monitoring was equally good in the three groups $(94 \%)$. There were no significant differences in non-trial medication between the groups, with antiplatelet therapy used in $95 \%$, fibrinolytic therapy in $92 \%$, intravenous nitrates in $22 \%$, oral $\beta$ blockers in $28 \%$ and antiarrhythmic agents in $10 \%$ of patients. None of the patients received nontrial oral nitrate or converting enzyme inhibitor.

\section{VENTRICULAR ARRHYTHMIAS}

During the whole 48 hour monitoring period, ventricular extrasystoles were significantly less frequent among patients allocated to nitrate than among patients allocated to placebo (Table 2 and fig $1 \mathrm{~A} ; 2 \mathrm{p}<0.02$ for the comparison with placebo), and less frequent in the captopril group too, though not significantly $(2 p=0.08$ for the comparison with placebo). The frequency of ventricular extrasystoles was higher in the first six hours of recording, but even during this period trial treatment seemed to be associated with a lower frequency of ventricular extrasystoles (analysis of variance $p=0.06 ; 2 p<0.05$ for nitrate $v$ placebo and $2 p=0.09$ for captopril $v$ placebo). Similarly, the frequency of multiple extrasystoles during the 48 hour monitoring period, was significantly less in the nitrate group (table 2 and figure $1 \mathrm{~B} ; 2 \mathrm{p}<0.02$ for the comparison with placebo) with a non-significant trend in the same direction in the captopril group. The numbers of episodes of ventricular tachycardia were lower, though not significantly, in the active treatment groups than in the placebo group (table 2 and figure 1C). All of these episodes were non-sustained, with the one patient who had ventricular fibrillation (captopril group) being successfully defibrillated and discharged alive.

There were no significant differences in the 
Table 1 Clinical characteristics of patients with analysable Holter monitoring

\begin{tabular}{lccr}
\hline & $\begin{array}{c}\text { Captopril } \\
(n=32)\end{array}$ & $\begin{array}{c}\text { Nitrate } \\
(n=31)\end{array}$ & $\begin{array}{c}\text { Placebo } \\
(n=37)\end{array}$ \\
\hline $\begin{array}{l}\text { Pre-randomisation data (mean (SEM)): } \\
\text { Age (yr) }\end{array}$ & $59(2)$ & $60(2)$ & $62(1)$ \\
Male (\%) & $27(84)$ & $26(83)$ & $31(84)$ \\
Systolic BP (mmHg) & $128(3)$ & $128(3)$ & $126(2)$ \\
Heart rate (bpm) & $73(3)$ & $74(2)$ & $76(2)$ \\
Hours from pain onset & $13(1)$ & $13(1)$ & $12(1)$ \\
Electrocardiogram (\%): & $15(47)$ & $10(32)$ & $11(30)$ \\
ST elevation anterior & $12(38)$ & $16(52)$ & $19(51)$ \\
ST elevation inferior & $1(3)$ & $1(3)$ & $0(0)$ \\
ST elevation other & $4(12)$ & $4(13)$ & $7(19)$ \\
No ST elevation & $32(100)$ & $30(97)$ & $36(97)$ \\
Post-randomisation data: & $318(44)$ & $337(59)$ & $299(37)$ \\
Infarction confirmed (\%) & & & $31(9)$ \\
Peak enzyme (AST(U/)(SEM) & $31(97)$ & $29(94)$ & $35(94)$ \\
Non-trial treatment during first 48 h (\%): & $28(88)$ & $30(97)$ & $34(91)$ \\
Antiplatelet & $6(19)$ & $4(13)$ & $11(30)$ \\
Fibrinolytic & $8(26)$ & $7(23)$ & $13(35)$ \\
Intravenous nitrate & $5(17)$ & $1(3)$ & $4(11)$ \\
Oral $\beta$ blocker & $9(28)$ & $10(33)$ & $9(24)$ \\
Antiarrhythmic & Diuretic & &
\end{tabular}

AST, aspartate aminotransferase; BP, blood pressure. There were no significant difference between the groups.
Table 3 Percentage of patients with ventricular arrhythmias recorded on Holter monitoring

\begin{tabular}{lcll}
\hline Arrhythmia & $\begin{array}{c}\text { Captopril } \\
(n=32)\end{array}$ & $\begin{array}{l}\text { Nitrate } \\
(n=31)\end{array}$ & $\begin{array}{l}\text { Placebo } \\
(n=37)\end{array}$ \\
\hline Ventricular extrasystoles & 100 & 100 & 100 \\
Multiple extrasystoles & 69 & 81 & 81 \\
Ventricular tachycardia & 53 & 55 & 57 \\
Idioventricular rhythm & 28 & $19^{\star}$ & 46 \\
\hline
\end{tabular}

$\star 2 p<0.05$ for the comparison with placebo.

onset of ventricular tachycardia or fibrillation. $^{22}$ Consequently, various antiarrhythmic agents have been used to suppress ventricular extrasystoles early after acute myocardial infarction. ${ }^{23}$ The prophylactic use of lignocaine has been shown to reduce the incidence of ventricular fibrillation after myocardial infarction, but this does not seem to be associated with any decrease in mortality (and lignocaine may even have an adverse effect on survival ${ }^{24}$ ). Ventricular arrhythmias are much less common in the later recovery phase of myocardial infarction, but frequent ventricular extrasystoles may nevertheless carry an adverse prognosis. ${ }^{25}$ Recent evidence from the CAST study, however, does not support the prophylactic suppression of asymptomatic ventricular extrasystoles with flecainide, encainide, or moricizine-all of which were associated with an increased mortality in this setting. ${ }^{2627}$ There is, therefore, little evidence at present to support the prophylactic use of class I antiarrhythmic agents either in the early or late phases of myocardial infarction. In contrast, $\beta$ blockers, which can block catecholamine stimulation of the heart and reduce blood pressure, have been shown in several controlled studies in humans not only to prevent ventricular arrhythmias (including ventricular fibrillation) but also to improve survival when used after myocardial infarction. ${ }^{28-30}$ This suggests that effects other than just direct antiarrhythmic properties of $\beta$ blockers may be important in preventing life-threatening arrhythmias during and after myocardial infarction.

The aim of the present Holter monitoring study was to provide controlled evidence about the effects of oral nitrates and oral converting enzyme inhibitors on ventricular arrhythmias early after acute myocardial infarction. Previous small studies of intravenous nitrates in acute myocardial infarction indicated that such treatment may reduce the incidence of ventricular arrhythmias in the early phase of myocardial infarction. ${ }^{12}{ }^{13}$ Experimental work

Table 2 Frequency of ventricular arrhythmias (mean (SEM) and median (range))

\begin{tabular}{|c|c|c|c|c|c|c|c|c|c|}
\hline \multirow[b]{2}{*}{ Arrhythmia } & \multicolumn{3}{|l|}{$0-6 h$} & \multicolumn{3}{|l|}{ 6-48h } & \multicolumn{3}{|l|}{ All periods } \\
\hline & $\begin{array}{l}\text { Captopril } \\
(n=32)\end{array}$ & $\begin{array}{l}\text { Nitrate } \\
(n=31)\end{array}$ & $\begin{array}{l}\text { Placebo } \\
(n=37)\end{array}$ & $\begin{array}{l}\text { Captopril } \\
(n=32)\end{array}$ & $\begin{array}{l}\text { Nitrate } \\
(n=31)\end{array}$ & $\begin{array}{l}\text { Placebo } \\
(n=37)\end{array}$ & $\begin{array}{l}\text { Captopril } \\
(n=32)\end{array}$ & $\begin{array}{l}\text { Nitrate } \\
(n=31)\end{array}$ & $\begin{array}{l}\text { Placebo } \\
(n=37)\end{array}$ \\
\hline VE h & $\begin{array}{l}36(13) \\
6(0-398)\end{array}$ & $\begin{array}{l}15(3) \\
10(0-100)\end{array}$ & $\begin{aligned} 139(47) \\
17(0-1202)\end{aligned}$ & $\begin{array}{l}13(6) \\
4(0-181)\end{array}$ & $\begin{array}{l}5(1) \\
3(0-24)\end{array}$ & $\begin{array}{l}54(29) \\
7(0-1040)\end{array}$ & $\begin{array}{l}16(6) \\
6(0-162)\end{array}$ & $\begin{array}{l}7(1)^{\star \star} \\
4(0-38)\end{array}$ & $\begin{array}{l}65(27) \\
10(0-932)\end{array}$ \\
\hline Mult/h & $\begin{array}{l}7(4) \\
0 \cdot 3 \\
(0-131)\end{array}$ & $\begin{array}{l}1(0 \cdot 2) \\
0.7(0-5)\end{array}$ & $\begin{array}{l}13(5) \\
1(0-144)\end{array}$ & $\begin{array}{l}1(1) \\
0 \cdot 1 \\
(0-24)\end{array}$ & $\begin{array}{l}0.3(0 \cdot 1)^{\star} \\
0.1(0-4)\end{array}$ & $\begin{array}{l}1(0.3) \\
0.5(0-8)\end{array}$ & $\begin{array}{l}2(1) \\
0 \cdot 2 \\
(0-22)\end{array}$ & $\begin{array}{l}0 \cdot 4(0 \cdot 1)^{\star \star} \\
0 \cdot 3(0-4)\end{array}$ & $\begin{array}{l}3(1) \\
0.5 \\
(0-19)\end{array}$ \\
\hline VT & $\begin{array}{l}1 \cdot 7(0 \cdot 5) \\
0(0-12)\end{array}$ & $\begin{array}{l}1 \cdot 1(0 \cdot 3) \\
0(0-7)\end{array}$ & $\begin{array}{l}2 \cdot 4(0 \cdot 8) \\
0(0-18)\end{array}$ & $\begin{array}{l}1.5(0.4) \\
0.5(0-9)\end{array}$ & $\begin{array}{l}1 \cdot 3(0 \cdot 4) \\
0(0-10)\end{array}$ & $\begin{array}{l}2 \cdot 3(0 \cdot 7) \\
0(0-15)\end{array}$ & $\begin{array}{l}3 \cdot 2(0 \cdot 8) \\
1(0-16)\end{array}$ & $\begin{array}{l}2 \cdot 4(0 \cdot 7) \\
1(0-14)\end{array}$ & $\begin{array}{l}4 \cdot 7(1 \cdot 3) \\
1(0-33)\end{array}$ \\
\hline
\end{tabular}

Mult, multiple extrasystoles; VE, ventricular extrasystoles; VT, ventricular tachycardia, $\star 2 \mathrm{p}<0.05$ and $\star \star 2 \mathrm{p}<0.02$ nitrate $v$ placebo (two-way comparisons were performed only where analysis of variance was $p<0.05$ ). 

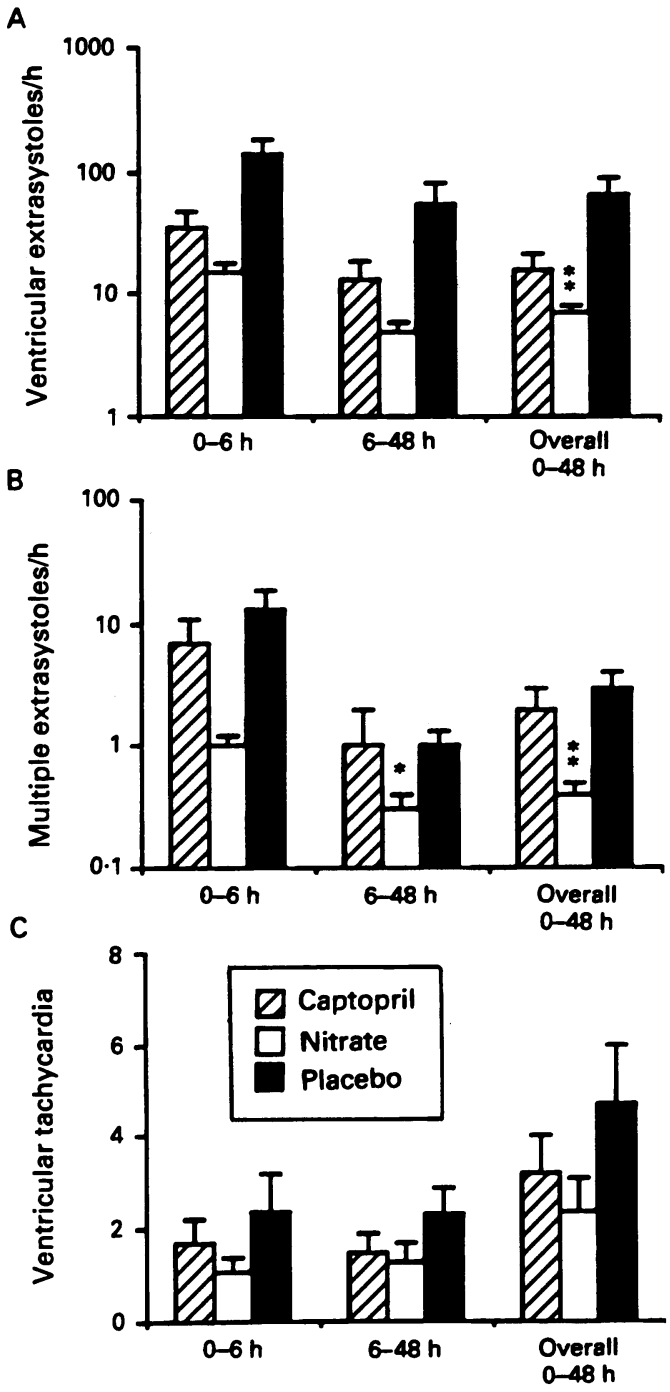

Frequency of arrhythmias in the three treatment groups during the first six hours after randomisation, the period 6 to 48 hours, and the whole period of Holter monitoring: (A) ventricular extrasystoles per hour (on a logarithmic scale); (B) episodes of multiple extrasystoles per hour (on a logarithmic scale); (C) episodes of ventricular tachycardia. $\left({ }^{*} 2 p<0.05,{ }^{\star} 2 p<0.02\right.$ nitrate $v$ placebo; two-way comparisons were performed only where analysis of variance showed $p<0.05$ ).

in a pig model of ischaemic heart disease showed that converting enzyme inhibitors also reduced the likelihood of ventricular fibrillation early after reperfusion and that ventricular tachycardia was less inducible in the chronic phase. ${ }^{31}$ In the present study, the frequency of arrhythmias was lower among patients allocated to oral nitrate and among those allocated to oral captopril than in the placebo group, although these differences were only conventionally significant for the nitrate group. There is no clear evidence for any direct electrophysiological properties of either nitrates or captopril $^{32}$ so any reduction in arrhythmias may be mediated mainly through their vasodilator properties, perhaps by a reduction in blood pressure and myocardial wall stress. Other mechanisms that have been suggested include salvage of ischaemic myocardium, improved ventricular function, reversal of electrolyte deficits, and benefits on coronary flow, but as yet there is little evidence in patients to substantiate these hypotheses. The apparent absence of any greater effect on arrhythmias of captopril compared with nitrate suggests that the potential antiadrenergic effects of converting enzyme inhibitors do not have an important role in reducing arrhythmias. Converting enzyme inhibitors and nitrates have previously been shown to have promising haemodynamic effects and to produce improvements in ventricular remodelling after acute myocardial infarction. ${ }^{8-11}$ These effects coupled with the present observations of a reduction in ventricular arrhythmias underline the need to determine directly whether these agents improve early and long term survival. This is currently being assessed in several large studies including ISIS $-4 .^{33}$

MF was a British Heart Foundation Junior Research Fellow during this study. RC is a British Heart Foundation Senior Research Fellow. The study was funded by Bristol-Myers Squibb, who manufacture captopril (Capoten). Isosorbide mononitrate (Monit) was donated by Stuart Pharmaceuticals, mononitrate (Monit) was donated by Stuart Pharmaceuticals, pendently of the companies. We thank Oxford Medilog for the provision of an Excell analyser and Jim Johnston for providing technical assistance.

1 Michorowski B, Ceremuzinski L. The renin-angiotensinaldosterone system and the clinical course of acute myocardial infarction. Eur Heart f 1983;4:259-64.

2 McAlpine HM, Morton JJ, Leckie B, Rumley A, Gillen G, Dargie HJ. Neuroendocrine activation after acute myocardial infarction. Br Heart $\mathcal{f} 1988 ; 60: 117-24$.

3 Magrini F, Reggiani P, Roberts N, Meazza R, Ciulla M, Zanchetti A. Effects of angiotensin and angiotensin blockade on coronary circulation and coronary reserve. Am f Med 1988;84 (suppl 3A):55-60.

4 Hutchins GM, Bulkley BH. Infarct expansion versus extension: two different complications of acute myoextension: two different complications of acute
cardial infarction. $A m \mathcal{F}$ Cardiol 1978;41:1127-32.

5 McKay RG, Pfeffer MA, Pasternak RC et al. Left ventricular remodelling after myocardial infarction: a corollary to infarct expansion. Circulation 1986;74:693-702.

6 James MA, Jones JV. Systolic wall stress and ventricula arrhythmia: the role of acute change in blood pressure in the isolated working rat heart. Clin Sci 1990;79. 499-504.

7 Sideris DA, Kontoyannis DA, Michalis L, Adractas A, Moulopoulos SD. Acute changes in blood pressure as a cause of cardiac arrhythmias. Eur Heart f 1987;8:45-52.

8 Pfeffer MA, Lamas GA, Vaughan DE, Parisi AF, Braunwald E. Effect of captopril on progressive ventricular dilatation after anterior myocardial infarction. $N$ Engl f Med 1988; 319:80-6.

9 Sharpe N, Murphy J, Smith H, Hannan S. Treatment of patients with symptomless left ventricular dysfunction patients with symptomless left ventricular dysf
after myocardial infarction. Lancet 1988;i:255-9.

10 Sharpe N, Smith H, Murphy J, Greaves S, Hart H, Gamble G. Early prevention of left ventricular dysfunction after myocardial infarction with angiotensin converting enzyme inhibition. Lancet 1991;337:872-6.

11 Jugdutt BI, Warnica JW. Intravenous nitroglycerin therapy to limit myocardial infarct size, expansion and complications. Effect of timing, dosage and infarct location. Circulation 1988;78:906-19.

12 Bussmann WD, Neumann $K$, Kaltenbach $M$. Effects of intravenous nitroglycerin on ventricular ectopic beats in acute myocardial infarction. Am Heart $\mathcal{f} 1984 ; 107$ : 940-4.

13 Derrida JP, Sal R, Chiche P. Favourable effects of prolonged nitroglycerin infusion in patients with acute myocardial nitroglycerin infusion in patients with

14 Cleland JGF, Dargie HJ, Hodsman GP, et al. Captopril in heart failure. A double blind controlled trial. Br Heart $\mathscr{f}$ 1984;52:530-5.

15 Webster MWI, Fitzpatrick MA, Nicholls MG, Ikram $\mathrm{H}$, Wells JE. Effect of enalapril on ventricular arrhythmias in congestive heart failure. Am f Cardiol 1985;56:566-9.

16 O'Doherty M, Tayler DI, Quinn E, Vincent R, Chamberlain DA. Five hundred patients with myocardial infarction monitored within one hour of symptoms. Br Med $\mathcal{f}$ 1983;286: 1405-8.

17 Campbell RWF, Murray A, Julian DG. Ventricular arrhythmias in the first 12 hours of acute myocardial infarction. Natural history study. Br Heart $\mathcal{F} 1981 ; 46: 351-7$.

18 Corbalan R, Verrier RL, Lown B. Differing mechanisms for ventricular vulnerability during coronary artery occlusion 
and release. Am Heart $₹$ 1976;92:223-30.

19 Ceremuzynski L Staszewska-Barczak J, HerbaczynskaCedro K. Cardiac rhythm disturbances and the release of catecholamines after acute coronary occlusion in dogs. Cardiovasc Res 1969;3:190-7.

20 Jewitt DE, Mercer CJ, Reid D, Valori C, Thomas M, Shillingford JP. Free noradrenaline and adrenaline excretion in relation to the development of cardiac arrhythmias and heart failure in patients with acute myocardial infarction. Lancet 1969;i:635-41.

21 Lie KJ, Wellens HJJ, Dorsnar E, Durrer D. Observations on patients with primary VF complicating acute MI. Circulation 1975;52:755-8.

22 Lown B, Klein MD, Hershberg PI. Coronary and precoronary care. $A m \mathcal{F}$ Med 1969;46:705-24.

23 Lown B, Wolf $M$. Approaches to sudden death from coronary disease. Circulation 1971;44:130-42.

24 MacMahon S, Collins R, Peto R, Koster R, Yusuf S. Effects of prophylactic lidocaine in suspected acute myocardial infarction. An overview of results from the randomised controlled trials. $\mathcal{F A M A}$ 1988;260:1910-6.

25 Bigger JT, Fleiss JL, Kleiger R, Miller P, Rolnitzky LM, and the Multicenter Post Infarction Research Group. The relationships among ventricular arrhythmias, left ventricular dysfunction, and mortality in the 2 years after myocardial infarction. Circulation 1984;69:250-8.

26 The Cardiac Arrhythmia Suppression Trial (CAST) Investigators. Preliminary report: effect of encainide and flecainide on mortality in a randomised trial of arrhythmia flecainide on mortality in a randomised trial of arrhythmia suppression after

27 Greene HL, Roden DM, Katz RJ, Woosley RL, Salerno DM, Henthorn RW and the CAST Investigators. The Cardiac Arrhythmia Suppression Trial: first CAST . . then CAST-II. $\mathcal{F}$ Am Coll Cardiol 1992;19:894-8.

28 Yusuf S, Peto R, Lewis J, Collins R, Sleight P. Beta Blockade during and after myocardial infarction: an overview or the randomised trials. Prog Cardiovasc Dis 1985;27:355-71.

29 ISIS-1 Collaborative Group. Randomised trial of intravenous atenolol among 16027 cases of suspected acute myocardial infarction: ISIS-1. Lancet 1986;ii:57-66.

30 "Olsson G, Rehnquist N. Evaluation of antiarrhythmic effect of metoprolol treatment after acute myocardial infarction: relationship between responses and survival during a 3 relationship between responses and surviva

31 De Graeff PA, De Langen CDJ, Van Gilst WH, et al. Protective effects of captopril against ischemia/reperfu-
sion-induced ventricular arrhythmias in vitro and in vivo. sion-induced ventricular arrhythmias in
$\mathrm{Am} \mathcal{F} \mathrm{Med} 1988 ; 84$ (Suppl 3A):67-74.

32 Hemsworth PD, Pallandi RT, Campbell TJ. Cardiac electrophysiological actions of captopril: lack of direct antiarrhythmic effects. Br $\mathcal{F}$ Pharmacol 1989;98:192-6.

33 ISIS-4 Collaborative Group. Fourth International Study of Infarct Survival: protocol for a large simple study of the effects of oral mononitrate, of oral captopril, and of intravenous magnesium. Am $\mathcal{F}$ Cardiol 1991;68:87-100. 